\title{
Covid-19 pandemisi döneminde tanı konulan bir toplum kaynaklı Legionella pneumophila pnömonisi olgusu
}

\section{A community-acquired pneumonia case due to Legionella pneumophila diagnosed during the Covid-19 pandemic period}

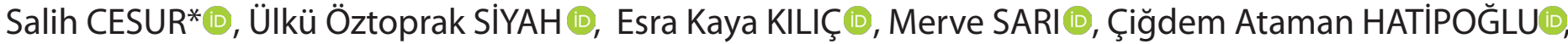 \\ Sami KINIKLI回
}

Sağlık Bilimleri Üniversitesi, Ankara Eğitim ve Araştırma Hastanesi, Enfeksiyon Hastalıkları ve Klinik Mikrobiyoloji Kliniği

\section{Öz}

Legionella pneumophila, hafif seyirli pnömoniden, ağır seyirli pnömoni ve çoklu organ yetmezliğine kadar değişebilen klinik seyir gösteren, toplum ve hastane kaynaklı pnömonilere neden olabilen, sporadik veya salgınlar şeklinde ortaya çıkabilen bir bakteriyel pnömoni etkenidir. Legionella pneumophila, akla getirilmezse ve tanıya yönelik testler istenmezse gözden kaçabilir. Burada, Covid -19 pandemisi döneminde acil servise yüksek ateş, öksürük, nefes darlığı şikayetleri ile başvuran ve idrarda Legionella antijen pozitifliği ile Legionelloz tanısı konulan bir olgu sunuldu. Olguda Covid-19 infeksiyonu bilgisayarlı tomografide tipik tutulum saptanmaması ve Covid-19 polimeraz zincir reaksiyonu testinin negatif saptanması ile ekarte edildi. Olguya Legionella pneumophila'ya yönelik levofloksasin tedavisi 14 güne tamamlandı. Klinik ve laboratuvar bulguları düzelen hasta taburcu edildi.

Sonuç olarak, Covid-19 pandemi döneminde Legionella pneumophila pnömonisinin Covid-19 pnömonisi ile karışabileceği, anamnez ve klinik bulguları legionella ile uyumlu hastalarda akılda tutulması gerektiği görüşündeyiz.

Anahtar kelimeler: Atipik pnömoni; Covid-19; Legionella pneumophila; ayırıcı tanı

Sorumlu Yazar*: Salih CESUR, Sağlık Bilimleri Üniversitesi, Ankara Eğitim ve Araştırma Hastanesi, Enfeksiyon Hastalıkları ve Klinik Mikrobiyoloji Kliniği 


\begin{abstract}
Legionella pneumophila is a bacterial pneumonia agent ranging from mild pneumonia to severe pneumonia and multi-organ failure, which can cause community and hospital-acquired pneumonia, sporadic or outbreaks. If Legionella pneumophila is not considered and diagnostic tests are not requested, it can be overlooked. Here, we present a case who was admitted to the emergency room with high fever, cough, and shortness of breath during the Covid-19 pandemic and was diagnosed with Legionellosis with Legionella antigen positivity in the urine. In the case, Covid-19 infection was ruled out by the absence of typical involvement in computed tomography and the negative detection of the Covid-19 polymerase chain reaction test. Levofloxacin treatment for Legionella pneumophila was applied to the patient for a period of 21 days. The patient, whose clinical and laboratory findings improved, was discharged.

In conclusion, we conclude that Legionella pneumophila pneumonia can be confused with Covid-19 pneumonia during the Covid-19 pandemic period and should be kept in mind in patients whose anamnesis and clinical findings are compatible with legionella.
\end{abstract}

Key words: Atypical pneumonia; Covid-19; Legionella pneumophila; differential diagnosis

\section{Giriş}

Lejyonella pneumophila, doğadaki sıcak veya soğuk çeşitli su kaynaklarında, şehir su şebekelerinde ve klima sistemlerinde, solunum cihazları, soğutma kulelerindeki sularda bulunabilen, fakültatif intrasellüler yerleşim gösteren Gram negatif bir bakteridir. İmmun yetmezlik, maligniteler, diabetes mellitus, kronik akciğer hastalığı, immunsüpresif ilaçlar (kortikosteroid vb.) sigara kullanımı, yaşlılık ve erkek cinsiyet Legionella infeksiyonu için risk faktörleri arasında yer alır [1-5]. Bulaş, kontamine suların bulunduğu çeşitli gereçlerden (duş başlıkları, solunum terapi cihazları, nemlendiriciler vb.) kaynaklanan aerosollerin solunum yoluyla alınmasıyla gerçekleşir [1,3,4,5].

Bu yazıda, Covid-19 pandemisi sırasında anamnez,muayene bulguları ve görüntüleme yöntemleri ile Legionella pneumophila (L.pneumophila) pnömonisi düşünülen ve idrarda Legionella antijen testi pozitifliği ve balgamda polimeraz zincir reaksiyonu (PZR) pozitifliği ile kesin tanı konulan bir olgu sunularak literatür gözden geçirildi.

\section{Olgu}

Ankara ilinde ikamet etmekte olan 41 yaşında erkek hasta yeni başlayan yüksek ateş öksürük nefes darlığı şikayeti ile acile başvurmuştu. Anamnezinden 3 gün önce Antalya'da bir otelde klimalı ortamda kaldığı ve duş aldığı, şikayetlerinin Ankara'ya döndükten sonraki gün başladığı öğrenildi. Özgeçmişinde ek hastalığı olmadığı, 20 paket/yıl sigara tükettiği öğrenildi. Fizik muayenesinde; ateş $39^{\circ} \mathrm{C}$, nabzı 100/dakika, kan basıncı 110/75 $\mathrm{mm} / \mathrm{Hg}$, solunum sayısı 27/ dakika, O2 saturasyonu \%90 idi. Genel durumu orta, bilinci açık ve oryante idi. Solunum sistemi muayenesinde, takipneik olan hastanın akciğer muayenesinde sağ akciğer bazalinde kaba raller mevcuttu. Diğer muayeneleri doğaldı. Laboratuvar testlerinde; lökosit sayısı $13.970 / \mathrm{mm} 3$, hemoglobin $13.6 \mathrm{gr} / \mathrm{dl}$, trombosit 182 000/mm 3 lenfosit sayısı $1480 / \mathrm{mm} 3$ eritrosit sedimantasyon hızı $48 \mathrm{~mm} / \mathrm{saat}$, C-reaktif protein $281 \mathrm{mg} / \mathrm{dl}$, üre $19 \mathrm{mg} / \mathrm{dl}$, kreatinin 0,9 mg/ $\mathrm{dl}$, sodyum $136 \mathrm{mmol} / \mathrm{L}$, potasyum $4,5 \mathrm{mmol} / \mathrm{L}$, aspartat aminotransferaz (AST) $39 \mathrm{U} / \mathrm{L}$, alanin aminotransferaz 38 $\mathrm{U} / \mathrm{L}$, laktik dehidrogenaz (LDH) $417 \mathrm{U} / \mathrm{L}$ (normali <232 U/L), total bilirübin $0.3 \mathrm{mg} / \mathrm{dl}$ idi. Hastadan kan ve idrar kültürleri alındı. Toraks bilgisayarlı tomografisinde 'Sağ akciğer alt lobda konsolidasyon ve buzlu cam tarzında dansite artımı gösteren infiltrasyon alanı' olarak rapor edildi. Hastadan alınan kan ve idrar kültürlerinde üreme olmadı. Balgamdan solunum yolu etkenlerine yönelik multiplex PZR testi (Bosphore solunum yolu patojenleri panel kiti V4, Anatolia geneworks,Türkiye) ve Covid-19 infeksiyonuna yönelik nazofarenks sürüntü örneğinde PZR testi ( Bioeksen, Türkiye ) istendi.

Hastanın anamnezinde uzun süre sigara kullanması, otelde duş alma öyküsü olması, klinik ve radyolojik olarak pnömoni bulgularının olması nedeniyle idrar örneği Legionella antijeni 
araştırılmak üzere Türkiye Halk Sağlığı Kurumu Mikrobiyoloji Referans Laboratuvarı'na gönderildi. Hastaya seftriakson $1 \times 2 \mathrm{gr}$ /gün intravenöz (I.V) ve levofloksasin 750 mg/gün IV başlandı.

Covid-19 PZR testi negatif saptandı. İmmünokromatografik yöntemle araştırılan idrarda L. pneumophila serogrup 1 antijeni pozitif sonuçlandı. Balgam örneğinden gönderilen multiplex PZR testinde de Legionella pneumophila pozitif saptandı, hastanın Sağlık Müdürlüğüne bildirimi yapıldı. Genel durumu düzelen, oksijen satürasyonu normal değerlerine dönen hastada levofloksasin tedavisi 14 güne tamamlamak üzere taburcu edildi.

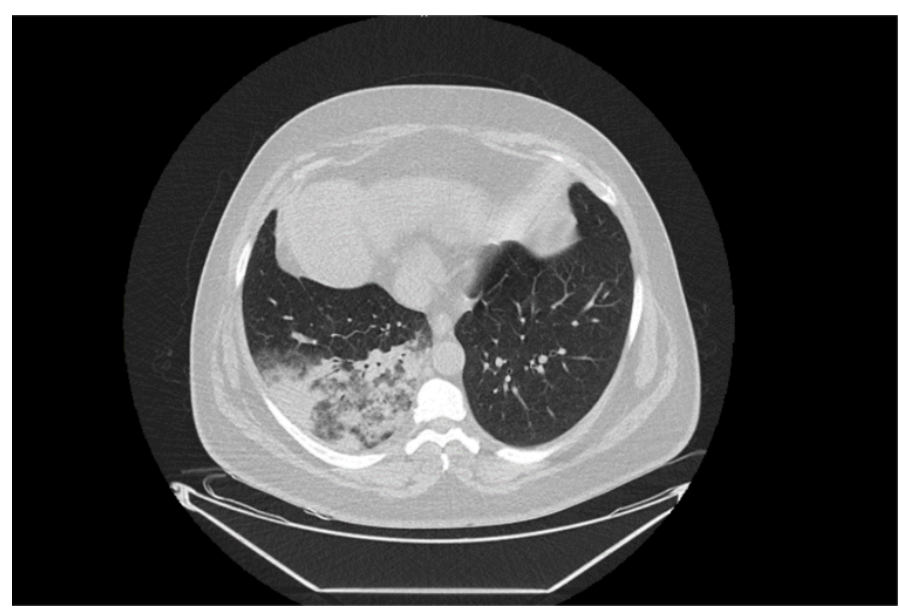

Resim. Hastanın yatış esnasında çekilen Toraks BT'sinde sağ akciğer alt lobda konsolidasyon ve buzlu cam tarzında dansite artımı

\section{Tartışma}

Pnömoni, Legionella infeksiyonunun en yaygın olarak tanımlanan bulgusudur ve Lejyoner hastalığı olarak da isimlendirilir [6]. Legionella pneumophila (L. pneumophila) insidansı toplumdan edinilmiş pnömonilerde \%1-30 bildirilmektedir [7,8].

L. pneumophila pnömonisinde klinik bulgular; hafif öksürük ve ateşten, yaygın pulmoner tutulumla karakterize pnömoni, akut respiratuvar distress sendromu ve çoklu organ yetersizliğine kadar değişen bir spektruma sahiptir [1-3,6,7].

L. pneumophila pnömonisinde hastalarda ateş, halsizlik, baş ağrısı, myalji, prodüktif olmayan öksürük gibi nonspesifik bulgular görülebilir. İshal olguların \%25-50'sinde görülür. Nörolojik semptomlar, baş ağrısı, letarji ve ileri evrede ensefalopatidir [1-3,5,6].

Sunduğumuz olguda fizik muayenede yüksek ateş $\left(39^{\circ} \mathrm{C}\right)$, öksürük, nefes darlığı, takipne ve sağ akciğer bazalde raller mevcuttu,ishal ve nörolojik semptomlar yoktu. Legionella pnömonisinde laboratuvar testlerinde transaminazlar, kreatinin fosfokinaz ve LDH yüksekliğiyle hiponatremi ve hipofosfatemi görülebilir [1,3,4,6,7]. Sunduğumuz hastada laboratuar değerlerinde LDH değerlerinde artış, lökositoz, CRP değeri ve sedimentasyon hızında yükseklik mevcuttu.

L. pneumophila tanısında, balgam, bronkoalveoler lavaj gibi alt solunum yolu örneklerinde kültür, direkt floresan antikor testi (DFA), serumda indirekt floresan antikor testi ya da ELISA testi, idrarda antijen testi veya polimeraz zincir reaksiyonu (PZR) testi kullanılmaktadır. $[1,2,4,6]$. Tanıda idrarda antijen testi, sadece L. pneumophila serogrup 1'i gösterir ve pnömoni olgularının \%85'inde serogrup 1'e bağlı gelişir. Bu testin duyarlılığı \%70, özgüllüğü ise \%100'dür [3,9]. Sunduğumuz hastada Legionella pnömonisi kesin tanısı idrarda Legionella antijen testinin pozitifliği ve balgamda multipleks PZR yöntemiyle Legionella pneumophila'nın saptanmasıyla kondu.

L. pneumophila'da akciğer grafisi bulguları genellikle nonspesifiktir. Kavitasyon ve apse oluşumu nadirdir. Sıklıkla hızla progresyon gösteren asimetrik yamalı infiltrasyonlar gözlenir. Akciğer tomografisinde L.pneomophila pnömonisinde sıklıkla perihiler bölgelerde, sınırları belirli, demarkasyon hatları oluşturan buzlu cam dansitesi şeklinde görülebilir [10].

Covid-19 infeksiyonuna bağlı akciğer tutulumunda BT'de farklı tutulum şekilleri görülebilmekle birlikte genellikle viral pnömoniyi düşündüren iki taraflı, periferik dağılıma sahip ve alt lobları tutan buzlu cam görüntüsü (opasiteleri) görülebilir. Buzlu cam görüntülerine konsolidasyon anormallikleri eşlik edebilir veya eşlik etmeyebilir [11].

Sunduğumuz olguda, Covid-19 pandemisi döneminde gelmesi, Covid-19 infeksiyonunda görülebilen yüksek ateş, öksürük ve nefes darlığı semptomlarının olması ve toraks BT'de sağ akciğer alt lobda konsolidasyon ve buzlu cam tarzında dansite artımı gösteren infiltrasyon alanı saptanması nedeniyle kesin tanı için Covid-19 PZR testi istendi.

Legionella infeksiyonunun tedavisinde levofloksasin, veya azitromisin tedavide ilk tercih ilaçlardır $[12,13]$. Legionella pnömonisi alternatif ilaçlar moksifloksasin, siprofloksasin , makrolidler ve tetrasiklinlerdir [13]. Cecci ve ark. [12] Legionella pnömonisinde mortalite oranını florokinolon bazlı tedavi alan hastalarda, florokinolon dışı tedavi alan hastalara göre daha düşük oranda bildirmişlerdir. 
L. pneumophila pnömonisinde tedavi süresi ortalama 7-14 gün arasında önerilmektedir $[1,10,13]$. Ağır olgularda tedavi süresi 21 güne kadar uzatılabilir [1].

Sunduğumuz hastada tedavide başlangıçta pnömoniye yönelik ampirik olarak seftriakson ve levofloksasin tedavisi başlandı, idrarda Legionella antijen testi ve balgamda Legionella PZR testi pozitif saptanınca tedavi levofloksasinle 14 güne tamamlandı.

Akıncı ve ark. [4] ateş, kuru öksürük ve konuşma bozukluğu şikayetleri ile başvuran, şikayetlerinden bir hafta önce otelde konaklama öyküsü olan ve 4 gün süreyle amoksisilin/ klavulonat kullanmasına rağmen şikayetleri geçmeyen 56 yaşında bir erkek hastada idrarda Legionella antijeninin pozitif saptanması ile tanı koymuşlardır. Hastanın kaldığı otelden alınan su örneklerinden yapılan kültürde Legionella pneumophila serogrup 1 üretilmiştir. Hastaya klaritromisin ve rifampisin kombinasyonu 21 gün süreyle uygulanmıştır.

Özyürek ve ark. [7] öksürük, ateş, halsizlik ve bir haftadır süren ishal yakınmaları olan 18 yaşında erkek hastada L.pneumophila'ya bağlı olarak gelişen pnömoni bildirmişlerdir. Hastada klinik ve radyolojik olarak pnömoni bulgularının saptanması, pnömoniye ishalin eşlik etmesi, transaminaz yüksekliği (AST 143 IU/L, ALT 104 U/L), hiponatremi (126 mEq/L) varlığı ve daha önceden kullanılan beta laktam antibiyotik tedavisine yanıt alınamaması nedeniyle L.pneumophila pnömonisi ön tanısı konulmuştur. Hastada kesin tanı indirekt fluoresan antikor (IFA) testi pozitifliği ile konmuştur.

Sunduğumuz olguda, anamnezde sigara kullanımı ve otelde duş alma öyküsü olması, klinik ve radyolojik olarak pnömoni bulgularının olması nedeniyle hastada Legionella pnömonisi olabileceği düşünüldü. Kesin tanı, idrar örneği Legionella antijeni pozitifliği ve balgam örneğinde multiplex PZR testinde de Legionella pneumophila pozitif saptanması ile konuldu. Hastaya levofloksasin tedavisinin 14 gün süreyle uygulanması planlandı.

Sonuç olarak, Covid-19 pandemi döneminde Legionella pneumophila pnömonisinin Covid-19 pnömonisiilekarışabileceği ve anamnez ve klinik bulguları legionella ile uyumlu hastalarda legionellozun akılda tutulması gerektiği görüşündeyiz

\section{Kaynaklar}

1. Siyah ÜÖ, Arslan K, Cesur S, Hatipoğlu ÇA, Sevim Ş, Kınıklı S. Akut Solunum Sıkıntısı Sendromuna İlerleyen Toplum Kaynaklı Legionella pneumophila Pnömonisi: Bir Olgu Sunumu. Klimik Dergisi 2020; 33: 95-99.

2. Mülazimoglu L, Yu VL. Can legionnaires' disease be diagnosed by clinical criteria?: a critical review. Chest 2001; 120: 1049-53.

3. Edelstein $\mathrm{PH}$, Roy $\mathrm{CR}$. Legionnaires' disease and Pontiac fever. In: Bennett JE, Dolin R, Blaser MJ, eds. Mandell, Douglas, and Bennett's Principles and Practice of Infectious Diseases. 8th ed. Philadelphia, PA: Elsevier Saunders, 2015: 234, 2633-44.

4. Akıncı E, Baran G, Erbay A, Çolpan A, Afacan G, Bodur H. Lejyoner Hastalığı: Bir Olgu Nedeniyle. T Klin J Microbiol-Infec 2003; 2: 28-31.

5. Stout JE, Yu VL. Legionellosis. New Engl J Med 1997; 337: 682-87.

6. Murdoch D, Chambers ST, Priest P. Clinical manifestations and diagnosis of Legionella infection. UptoDate 2020.

7. Özyürek S, Şimşek S, Hocaoğlu B, Hitit G, Göktaş P. Toplumdan Edinilmiş Bir Legionella pneumophila Pnömonisi Olgusu. Flora 1997; 3: 212-15.

8. Torres A, Serra-Batlles. Severe Community-acquired Pneumonia. Am Rev Respir Dis 1991; 144: 312-8.

9. Erdogan H, Erdogan A, Lakamdayali H, Yilmaz A, Arslan H. Travelassociated Legionnaires disease: Clinical features of 17 cases and a review of the literature. Diagn Microbiol Infect Dis. 2010; 68: 297-303.

10. Küpeli E. Atipik pnömoniler. Şen N, Özhan MH (Editör) Pnömoni. Türkiye Solunum Araştırmaları Derneği, Eğitim Kitapları Serisi yayınları, 2017: 83-111.

11. McIntosh K. Coronavirus disease 2019 (COVID-19): Clinical features. UptoDate 2021.

12. Cecchini J, Tuffet $S$, Sonneville R et al. Antimicrobial strategy for severe community-acquired legionnaires' disease: A multicentre retrospective observational study. J Antimicrob Chemother. 2017; 72: 1502-9.

13. Murdoch D, Chambers ST, Priest P. Treatment and prevention of Legionella infection. UptoDate 2020. 